\title{
Synthesis of ambergris odorant ent-ambrox
}

\author{
Rosana A. Giacomini, ${ }^{a}$ Paulo C. M. de L. Miranda, ${ }^{a}$ Lúcia H. B. Baptistellab and \\ Paulo M. Imamura ${ }^{\text {* }}$ *
}

a Laboratório de Ciências Químicas (LCQUI), UENF, Campo de Goytacazes, RJ, ${ }^{\mathrm{b}}$ Instituto de Química - UNICAMP, C.P. 6154, CEP 13084-971,Campinas, São Paulo, Brazil E-mail: imam@iqm.unicamp.br

\section{Dedicated to Prof. Dr. Edmundo A. Rúveda on the occasion of his $70^{\text {th }}$ anniversary (received 08 Jul 03; accepted 27 Sep 03; published on the web 29 Sep 03)}

\begin{abstract}
A synthesis of the ambergris odorant ent-ambrox starting from (-)-ozic acid is described.
\end{abstract}

Keywords: Ambergris odorant, ent-ambrox, ozic acid, diterpene

\section{Introduction}

Ambergris is a metabolic product of the sperm whale (Physeter macrocephalus) and is considered one of the most valuable animal perfumes besides civet, musk and castoroleum. ${ }^{1}$ Due to enforced whale protection, the use of ambergris in perfumery has been abolished, thus encouraging chemists to search for new synthetic substitutes. (-)-Tetranorlabdane oxide (1) is one of the commercially important products, synthesized for the first time by Stoll and Hinder in $1950,{ }^{2}$ and is commonly known under the trade names Ambrox ${ }^{\circledR}$ (Firmenich), Amberlyn ${ }^{\circledR}$ (Quest) and Ambroxan ${ }^{\circledR}$ (Henkel). ${ }^{3}$

Nowadays, an increasing number of publications on this topic demonstrates the great interest and importance of ambergris derivatives. ${ }^{4}$ Many racemic ${ }^{5}$ and chiral syntheses have been described in the literature. Among the chiral syntheses, several used naturally occurring terpenes as starting materials, for example, monoterpenes such as $(+)$-carvone ${ }^{6}$ and thujone, ${ }^{7,8}$ sesquiterpenes such as (-)-drimenol ${ }^{9}$ or diterpenes such as (-)-labdanolic acid, ${ }^{4 a, 10}(+)$-larixol, ${ }^{11}$ (+)-cis-abienol, ${ }^{12}$ (-)-levopimaric acid, ${ }^{13}$ (-)-abietic acid, ${ }^{14}(-)$-communic acid, ${ }^{15}(+)$-manoyl oxide, $^{16}$ and (-)-sclareol. ${ }^{17}$ More recently, polyenes such as geranylacetone ${ }^{18}$ and homofarnesol $^{4 b, 19}$ have been used for the synthesis of Ambrox ${ }^{\circledR}$ and enzymatic reactions have been employed for the resolution. ${ }^{20}$ As part of our current interest on the synthesis of terpenoids and analogues starting from readily available natural resinic acids, we had synthesized the enantiomer, ent-ambrox (2), with 46\% ee starting from (-)-copalic acid. ${ }^{21}$ Continuing our 
research program and in order to obtain pure ent-ambrox, we undertook the synthesis of 2 starting from (-)-ozic acid (3a) (Figure 1). This acid is the main component of the seed pod extract of Hymenaea courbaril var. altissima ${ }^{22}$ and can be obtained readily as the methyl ester $\mathbf{3 b}$, after esterification with diazomethane.

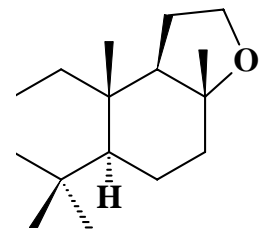

1

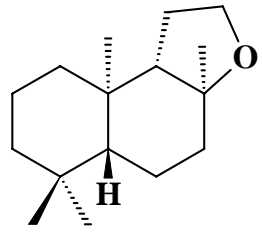

2

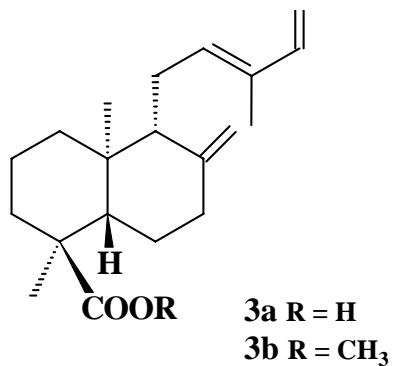

Figure 1

\section{Results and Discussion}

The reaction of $\mathbf{3 b}$ with a stream of ozone followed by treatment with $\mathrm{PPh}_{3}$ furnished the corresponding keto-aldehyde 4 in $85 \%$ yield (Scheme 1). In order to selectively protect the carbonyl group of the aldehyde, treatment of $\mathbf{4}$ with ethylene glycol in benzene using camphorsulfonic acid as catalyst gave the desired compound 5 in $90 \%$ yield. When $p$-TsOH was used as the catalyst, the furan derivative 6 was obtained as the sole product, in $48 \%$ yield, instead of the desired 5. Compound $\mathbf{6}$ was characterized through NMR spectroscopic analysis. The presence of two olefinic hydrogens at $\delta 6.08(\mathrm{~d}, 1 \mathrm{H}, J=2.20)$ and at $\delta 7.11(\mathrm{~d}, 1 \mathrm{H}, J=2.2 \mathrm{~Hz})$ in the ${ }^{1} \mathrm{H}$ NMR spectra and four sp ${ }^{2}$ carbons at $\delta 106.7(\mathrm{CH}), 129.8(\mathrm{C}), 140.7(\mathrm{CH})$ and at $\delta 148.3$ (C) in the ${ }^{13} \mathrm{C}$ NMR spectra indicates clearly that we had a furan unit in the molecule.

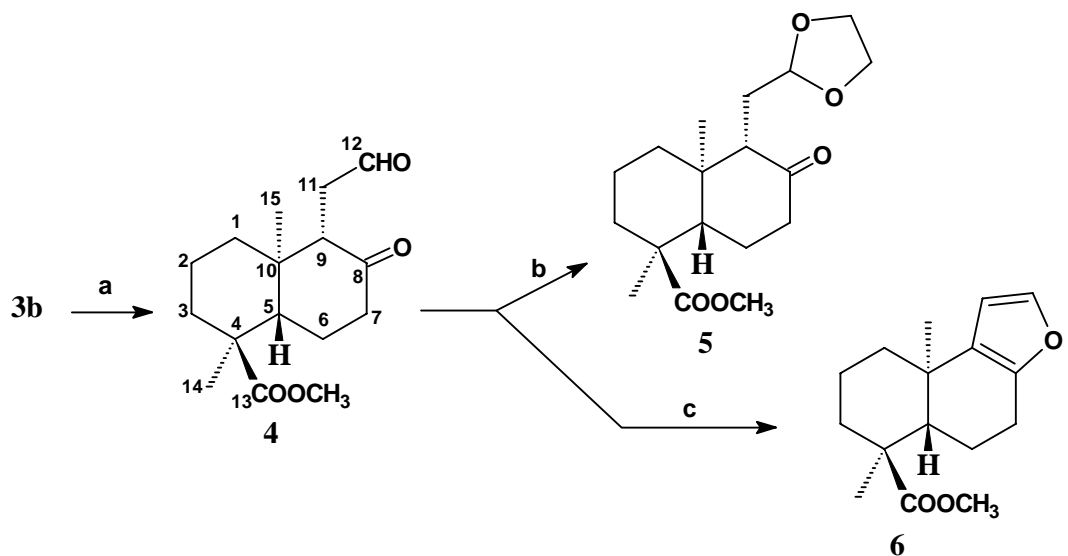

Scheme 1. a) i. $\mathrm{O}_{3}, \mathrm{CH}_{2} \mathrm{Cl}_{2},-78^{\circ} \mathrm{C}$, ii. $\mathrm{PPh}_{3}, \mathrm{rt}, 85 \%$; b) camphorsulfonic acid, benzene, reflux, $90 \%$, c) $p$-TsOH, benzene, reflux, $48 \%$. 
Following the synthetic sequence, the intermediate $\mathbf{5}$ was submitted to the Wittig reaction using methyltriphenylphosphonium bromide and $n$-BuLi as the base. However, this met with failure and starting material was recovered. After some attempts, we obtained the olefination product by treating 5 with $\mathrm{CH}_{2} \mathrm{Br}_{2} / \mathrm{Zn} / \mathrm{TiCl}_{4}$ in $\mathrm{CH}_{2} \mathrm{Cl}_{2}$, following the Lombardo's protocol, ${ }^{23}$ where 7 was obtained in $73 \%$ yield (Scheme 2).

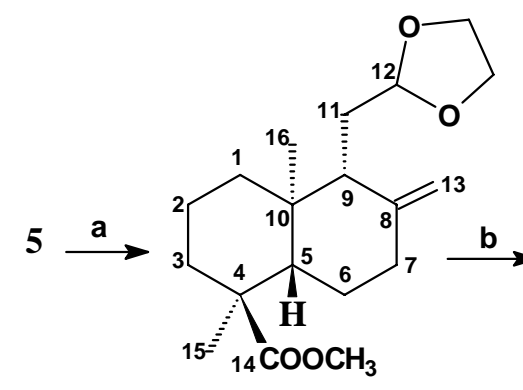

7

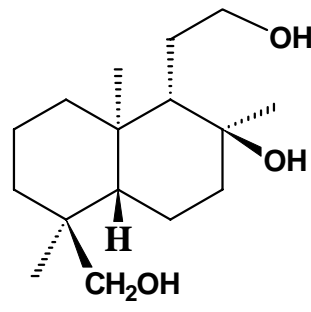

10

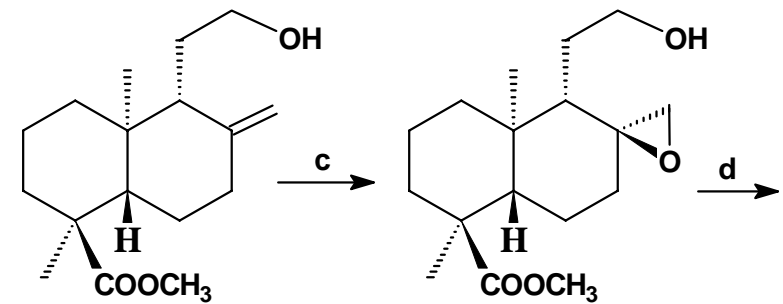

8

9

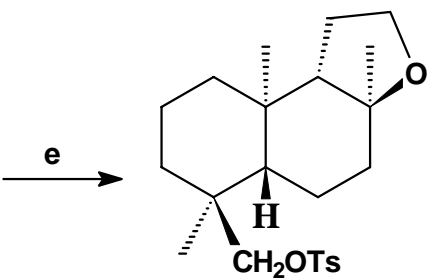

11

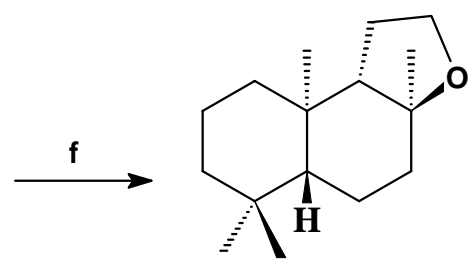

2

Scheme 2. (a) Zn, $\mathrm{TiCl}_{4}, \mathrm{CH}_{2} \mathrm{Br}_{2}, \mathrm{CH}_{2} \mathrm{Cl}_{2}$, rt, 73\%; (b) i. THF, $\mathrm{HCl} 1 \%$, rt; ii. $\mathrm{NaBH}_{4}, \mathrm{MeOH}$, rt, 81\%; (c) $m \mathrm{CPBA}, \mathrm{CH}_{2} \mathrm{Cl}_{2}$, rt, 90\%; (d) $\mathrm{LiAlH}_{4}$, THF, reflux, 86\%; (e) TsCl, Py, rt, 62\%; (f) i. $\mathrm{NaI}, \mathrm{Zn}, \mathrm{DMF}, 120^{\circ} \mathrm{C}$; ii. $\mathrm{mCPBA}, \mathrm{CH}_{2} \mathrm{Cl}_{2}$, rt, $58 \%$ (two steps).

Next, the deprotection of the ketal using $1 \% \mathrm{HCl}$ in THF furnished an unstable aldehyde which decomposed during purification. Thus, after deprotection, the crude material was treated with $\mathrm{NaBH}_{4}$ in $\mathrm{MeOH}$ to furnish the corresponding hydroxy ester 8 in $81 \%$ yield. Epoxidation of 8 with $m \mathrm{CPBA}$ in $\mathrm{CH}_{2} \mathrm{Cl}_{2}$ followed by reduction of the epoxide 9 with $\mathrm{LiAlH}_{4}$, furnished the triol 10 in 77\% overall yield. Since it is known that treatment of hydroxy groups at C-8 and C12 with 1.0 equivalent of $\mathrm{MsCl}^{21}$ leads to tetrahydrofuran derivatives, triol $\mathbf{1 0}$ was treated with 2.0 equivalent of $\mathrm{TsCl}$ in pyridine. As expected, monotosylate $\mathbf{1 1}$ was obtained in $62 \%$ yield. Finally, treatment of $\mathbf{1 1}$ with $\mathrm{NaI}$ and activated $\mathrm{Zn}$ in DMF at $120^{\circ} \mathrm{C}$ furnished ent-ambrox (2) together with an inseparable mixture of isomeric olefins. The presence of unsaturated compounds was detected by ${ }^{1} \mathrm{H}$ NMR spectral analysis, which showed signals between $\delta 4.0$ and 5.2, characteristic of olefinic hydrogens and also by ${ }^{13} \mathrm{C}$ NMR spectra which showed signals of $\mathrm{sp}^{2}$ carbons between $\delta 120$ and 140 . Analysis by GC/MS showed the presence of at least 4 compounds with masses 2 Daltons less than the expected product. Based on these data, it was 
possible to infer that unexpected rearrangement products were obtained during the reduction reaction. Due to the difficulty observed in purification of the desired product, the crude mixture was treated with $m C P B A$ and after purification using silica gel column chromatography, entambrox (2) was obtained in a 58\% overall yield. All spectroscopic data were in good agreement with those reported previously. ${ }^{21,24}$

\section{Experimental Section}

General Procedures. Melting points were determined on a Micro-Química MQAPF-31 apparatus and are uncorrected. IR spectra were recorded on a Perkin Elmer 1600 FTIR or on a BOMEM MB-100 instrument. ${ }^{1} \mathrm{H}$ NMR and ${ }^{13} \mathrm{C}$ NMR spectra were recorded on a Varian Gemini 2000 spectrometer at $300 \mathrm{MHz}$ and $75 \mathrm{MHz}$, respectively, or on a Varian Inova 500 spectrometer at $500 \mathrm{MHz}$ and $125 \mathrm{MHz}$, respectively, with $\mathrm{CDCl}_{3}$ as solvent and TMS as internal standard. GC/MS analyses were carried out using a HP-5990/5970 system equipped with J\&W Scientific DB-5 [fused silica capillary column (30mx0.25mmx0.25 $\mu \mathrm{m})$ ] and using helium as the carrier gas. High resolution mass spectra were obtained on a VG Autospec-Micromass instrument. Elemental analyses were performed with a Perkin-Elmer $2400 \mathrm{CHN}$ analyzer. Optical rotations were measured with a Carl Zeiss photoelectric polarimeter.

Keto-aldehyde 4. To a solution of (-)-methyl ozate (3b) (2.4 g, $7.59 \mathrm{mmol})$ in $50 \mathrm{~mL}$ of $\mathrm{CH}_{2} \mathrm{Cl}_{2}$ at $-78^{\circ} \mathrm{C}$, was bubbled a stream of ozone $(200 \mathrm{~mL} / \mathrm{min})$ over $5 \mathrm{~h}$ until a blue color persisted. The excess of ozone was eliminated by flushing nitrogen through mixture and then $\mathrm{PPh}_{3}(7.5 \mathrm{~g}, 28.6$ mmol) was added and the mixture was stirred for $12 \mathrm{~h}$ at room temperature. After removal of the solvent under reduced pressure and purification of the residue by column chromatography (silica gel, petroleum ether:EtOAc, 85:15) 4 (1.8 g, 85\%) was obtained as colorless crystals; mp. 74-76 ${ }^{\circ} \mathrm{C} ;[\alpha]_{D}^{20}+54.2$ (c = 2.5, $\mathrm{CHCl}_{3}$ ); IR (KBr) $v_{\max }: 2935,2820,2722,1724,1440,1387$, 1249, 1190, 1168, 1147, 1116, 964, $677 \mathrm{~cm}^{-1}$; NMR (500 MHz, $\left.\mathrm{CDCl}_{3}\right) \delta: 0.78$ (3H, s, H-15), 1.22 (3H, s, H-14), 1.33 (1H, dd, $J=4.8,12.9$ Hz, H-1), 1.58-1.63 (3H, m, H-1', H-2), 1.64-1.67 (1H, m, H-6), 1.69 (1H, dt, J = 1.7, $2.9 \mathrm{~Hz}, \mathrm{H}-3), 1.71-1.82(2 \mathrm{H}, \mathrm{m}, \mathrm{H}-3$ ', H-6'), 2.23-2.29 (1H, m, H-7) 2.45-2.50 (3H, m, H-5, H-11), 2.96 (1H, bs, H-9), 2.97 (1H, dq, $J=9.5$ Hz; $J=1.0 \mathrm{~Hz}$, H-7'), 3.72 (3H, s, OC$\left.{ }_{3}\right)$, $9.83(1 \mathrm{H}, \mathrm{s}, \mathrm{H}-12) ;{ }^{13} \mathrm{C}$ NMR (125 MHz, $\left.\mathrm{CDCl}_{3}\right) \delta: 15.6$ (C-15), 16.9 (C-14), 17.8 (C-2), 25.5 (C-6), 37.1 (C-3), 37.1 (C-7), 38.5 (C-1), 40.6 (C-10), 41.3 (C-11), 47.4 (C-4), 48.1 (C-5), 52.5 (-OCيH 3 ), 58.4 (C-9), 178.8 (C-13), 201.2 (C-12), 209.8 (C-8); MS (70 eV) $\mathrm{m} / \mathrm{z}$ (relative intensity): 224 (39), 252 (19), 281 (16)123 (100); Anal. Calcd. for $\mathrm{C}_{16} \mathrm{H}_{24} \mathrm{O}_{4}$ : C, 68.55; H, 8.63. Found: C, 68.66; H, 8.65.

Ketal 5. To a solution of aldehyde $4(500 \mathrm{mg}, 1.78 \mathrm{mmol})$ in dry benzene $(30.0 \mathrm{~mL})$ was added ethylene glycol $(0.12 \mathrm{~mL}, 2.14 \mathrm{mmol})$ and a catalytic amount of camphorsulfonic acid (2 mg). After refluxing for $1 \mathrm{~h}$ using a Dean-Stark apparatus filled with benzene, the mixture was cooled to room temperature and the solution was washed with $5 \%$ aqueous $\mathrm{NaHCO}_{3}$ solution and brine, 
dried with anhydrous $\mathrm{MgSO}_{4}$ and the solvent was removed under reduced pressure. The residue was chromatographed on silica gel (petroleum ether:EtOAc, 85:15) to give 5 (500 mg, 90\%) as colorless crystals; mp. $118-119^{\circ} \mathrm{C} ;[\alpha]_{D}^{20}+43.2$ (c = 2.6, $\mathrm{CHCl}_{3}$ ); IR (KBr) v max $_{2}$ 2950, 2886, 1722, 1471, 1429, 1410, 1389, 1247, 1189, 1168, 1143, 1115, 1050, 1014, 979, 959, $855 \mathrm{~cm}^{-1}$; ${ }^{1} \mathrm{H}$ NMR (500 MHz, $\mathrm{CDCl}_{3}$ ) $\delta: 0.71$ (3H, s, H-15), 1.17 (3H, s, H-14), 1.32 (1H, dt, J = 4.2, 12.9 Hz, H-1), 1.43 (1H, dd, $J=6.8,13.4$ Hz, H-11), 1.49-1.68 (4H, m, H-2, H-2', H-3, H-6), 1.691.79 (3H, m, H-1', H-3, H-6), 2.28 (1H, ddd, $J=2.9,10.0,16.4$ Hz, H-11'), 2.37-2.44 (4H, m, H-

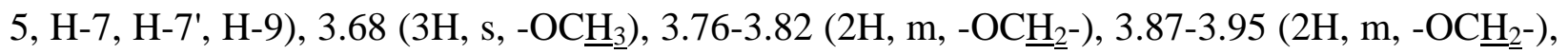
4.80 (1H, dd, $J=2.9,6.8 \mathrm{~Hz}, \mathrm{H}-12) ;{ }^{13} \mathrm{C} \mathrm{NMR}$ (125 MHz, $\mathrm{CDCl}_{3}$ ) $\delta: 14.9$ (C-15), 16.5 (C-14), 17.7 (C-2), 25.8 (C-6), 25.9 (C-11), 36.9 (C-3), 37.9 (C-1), 41.2 (C-4), 41.8 (C-7), 47.3 (C-10),

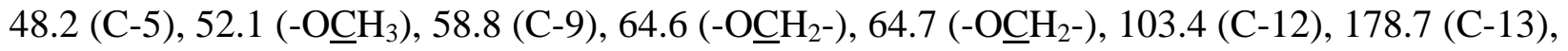
210.5 (C-8); MS (70 eV) m/z (relative intensity): 324 (5), 265 (9), 163 (12), 121 (6), 87 (100), 73 (59); HRMS m/z 324.19367, calcd. for $\mathrm{C}_{18} \mathrm{H}_{28} \mathrm{O}_{5} 324.19366$.

Furan 6. To a solution of aldehyde $4(20,0 \mathrm{mg}, 0.07 \mathrm{mmol})$ in dry benzene $(10.0 \mathrm{~mL})$ was added ethylene glycol $(0.1 \mathrm{~mL}, 1.7 \mathrm{mmol})$ and a catalytic amount of $p$-TsOH $(1 \mathrm{mg})$. After refluxing for 30 min. using a Dean-Stark apparatus filled with benzene, the mixture was cooled to room temperature and the solution was washed with $5 \%$ aqueous $\mathrm{NaHCO}_{3}$ solution, brine and dried with anhydrous $\mathrm{MgSO}_{4}$ and the solvent was removed under reduced pressure. The residue was chromatographed on silica gel (petroleum ether:EtOAc, 95:5) to give a product proposed as 6 (9 mg, 48\%) as a yellowish oil. ${ }^{1} \mathrm{H}$ NMR (300 MHz, $\left.\mathrm{CDCl}_{3}\right) \delta: 1.07$ (3H, s, H-15), 1.15 (3H, s, H14), 1.30-1.39 (2H, m, H-1, H-6), 1.50-1.78 (5H, m, H-2, H-2', H-3, H-3', H-6'), 1.82-1.86 (1H, m, H-1'), 2.06 (1H, dd, $J=1.8,12.1, \mathrm{H}-5), 2.51-2.56$ (2H, m, H-7, H-7'), 3.58 (3H, s, -OC $\left.\underline{H}_{3}\right)$, $6.08(1 \mathrm{H}, \mathrm{d}, J=2.2 \mathrm{~Hz}, \mathrm{H}-11), 7.11(1 \mathrm{H}, \mathrm{d}, J=2.2 \mathrm{~Hz}, \mathrm{H}-12) ;{ }^{13} \mathrm{C}$ NMR $\left(75 \mathrm{MHz}, \mathrm{CDCl}_{3}\right) \delta$ : 16.1 (C-14), 18.0 (C-2), 21.7 (C-6), 23.6 (C-15), 24.1 (C-7), 33.8 (10), 36.9 (C-3) 37.4 (C-1), 46.5 (C-5), 47.2 (C-4), $51.9\left(-\mathrm{OCH}_{3}\right), 106.7$ (C-11), 129.8 (C-9), 140.7 (C-12), 148.3 (C-8), 179.0 (C-13); MS ( $\mathrm{m} / \mathrm{z}) 262\left(\mathrm{M}^{+}\right)$.

Olefin 7. To a suspension of activated zinc dust $(900 \mathrm{mg}, 13.8 \mathrm{mmol})$ in dry THF $(8.0 \mathrm{~mL})$, containing $\mathrm{CH}_{2} \mathrm{Br}_{2}(0.32 \mathrm{~mL}, 4.56 \mathrm{mmol})$ at $-40^{\circ} \mathrm{C}$, was added dropwise, $\mathrm{TiCl}_{4}(0.40 \mathrm{~mL}$, $2.32 \mathrm{mmol}$ ) with vigorous stirring. The cooling bath was then removed and the temperature was left to rise to $5^{\circ} \mathrm{C}$. After stirring the mixture for 3 days, the solution was diluted with $\mathrm{CH}_{2} \mathrm{Cl}_{2}$ $(1.6 \mathrm{~mL})$, cooled to $0^{\circ} \mathrm{C}$ and a solution of ketal 5 (750 mg, $\left.2.32 \mathrm{mmol}\right)$ in dry $\mathrm{CH}_{2} \mathrm{Cl}_{2}(1.6 \mathrm{~mL})$ was added. The cooling bath was then removed and after stirring the reaction for $1.5 \mathrm{~h}$ at room temperature, the mixture was diluted with $n$-pentane $(10 \mathrm{~mL})$ and a saturated $\mathrm{NaHCO}_{3}$ solution ( $2 \mathrm{~mL}$ ) was added carefully. The organic phase was separated and the aqueous phase was extracted with $n$-pentane ( 2 x $15 \mathrm{~mL}$ ). The combined organic phases were washed with brine, dried with anhydrous $\mathrm{Na}_{2} \mathrm{SO}_{4}$ and filtered and the solvent was removed under reduced pressure. The residue was chromatographed on silica gel (petroleum ether:EtOAc, 95:5) to give 7 (540 mg, $73 \%$ ) as colorless a solid; mp. $115-116^{\circ} \mathrm{C}$; $[\alpha]_{D}^{20}-21.7$ (c = 2.1, $\mathrm{CHCl}_{3}$ ); IR (KBr) $v_{\max }$ : 2949, 2887, 2865, 1713, 1644, 1437, 1411, 1388, 1243, 1129, 1104, $1049 \mathrm{~cm}^{-1}$; ${ }^{1} \mathrm{H}$ NMR (500 MHz, $\mathrm{CDCl}_{3}$ ) $\delta: 0.70$ (3H, s, H-16), 1.15 (3H, s, H-15), 1.20-1.24 (2H, m, H-1, H-6), 1.45 (1H, dq, $J=$ 
4.3, 12.8 Hz, H-6'), 1.55-1.61 (2H, m, H-2, H-2'), 1.66-1.80 (4H, m, H-1', H-3, H-3', H-11), 1.89 $(1 \mathrm{H}, \mathrm{dt}, J=2.1,12.7 \mathrm{~Hz}, \mathrm{H}-11$ '), 2.00-2.07 (2H, m, H-5, H-9), 2.09 (1H, dd, $J=4.3,12.8 \mathrm{~Hz}, \mathrm{H}-$ 7), 2.35 (1H, ddd, $J=2.1,4.3,12.8 \mathrm{~Hz}, \mathrm{H}-7$ '), 3.66 (3H, s, $\left.-\mathrm{OC}_{3} 3\right), 3.81-3.84$ (2H, m, $\left.-\mathrm{OC}_{2} \underline{2}^{-}\right)$,

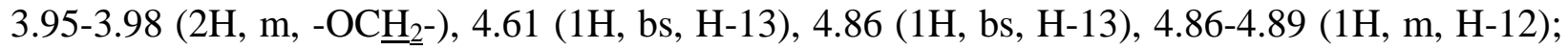
${ }^{13} \mathrm{C}$ NMR (125 MHz, $\mathrm{CDCl}_{3}$ ) $\delta: 14.6$ (C-16), 16.5 (C-15), 18.4 (C-2), 26.6 (C-6), 28.5 (C-11), 36.9 (C-3), 37.6 (C-7), 37.9 (C-1), 38.5 (C-4), 47.7 (C-10), 49.5 (C-5), 51.8 (-OC_H $), 52.0$ (C-9),

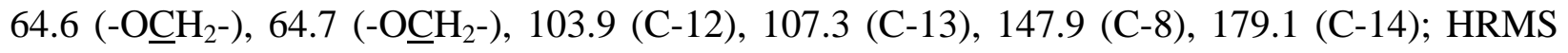
$\mathrm{m} / \mathrm{z}$ 322.21458, calcd. for $\mathrm{C}_{19} \mathrm{H}_{30} \mathrm{O}_{4} 322.21441$.

Hydroxy-olefin 8. To a solution of $7(100 \mathrm{mg}, 0.31 \mathrm{mmol})$ in $\mathrm{THF}(6 \mathrm{~mL})$ at $0^{\circ} \mathrm{C}$ was added, drop by drop, an aqueous $1 \% \mathrm{HCl}$ solution $(2 \mathrm{~mL})$. After removal of the cooling bath, the mixture was stirred for $12 \mathrm{~h}$ and then was neutralized by adding $5 \%$ aqueous $\mathrm{NaHCO}_{3}$ solution and extracted with $\mathrm{Et}_{2} \mathrm{O}$. The organic layer was dried with anhydrous $\mathrm{Na}_{2} \mathrm{SO}_{4}$ and the solvent was removed under reduced pressure. The crude material, without any purification, was dissolved in $\mathrm{MeOH}\left(12 \mathrm{~mL}\right.$ ) and $\mathrm{NaBH}_{4}$ (30 mg, $0.79 \mathrm{mmol}$ ) was added. After stirring the mixture at room temperature for $2 \mathrm{~h}$, the solvent was removed under reduced pressure and the residue was dissolved in $\mathrm{CH}_{2} \mathrm{Cl}_{2}(20 \mathrm{~mL})$. The organic phase was washed with a saturated aqueous solution of $\mathrm{NH}_{4} \mathrm{Cl}$ and dried with anhydrous $\mathrm{Na}_{2} \mathrm{SO}_{4}$. The solvent was removed under reduced pressure. The residue was then chromatographed on silica gel (petroleum ether:EtOAc, 85:15) to give 8 (77 mg, 89\%) as a colorless oil; $[\alpha]_{D}^{20}-15.3$ (c $=6.2, \mathrm{CHCl}_{3}$ ); IR (film) $v_{\text {max: }}$ : 3383, 3079, 2930, 2866, 1726, 1643, 1445, 1387, 1245, 1197, 1173, 1129, 1046, 981, 892, 737 $\mathrm{cm}^{-1}$; ${ }^{1} \mathrm{H}$ NMR (300 MHz, $\mathrm{CDCl}_{3}$ ) $\delta: 0.72$ (3H, s, H-16), 1.15 (3H, s, H-15), 1.19-1.26 (2H, m, H-1, H-6), 1.37(1H, bs, -OH), 1.46 (1H, dq, $J=4.4,12.8$ Hz, H-6'), 1.54-1.87 (8H, m, H-1', H-2, H-2', H-3, H-3', H-9, H-11, H-11'), 1.99 (1H, dd, $J=2.9,12.5$ Hz, H-5), 2.05 (1H, dt, $J=5.1$, $12.8 \mathrm{~Hz}, \mathrm{H}-7), 2.35$ (1H, ddd, $J=2.2,4.4,12.8 \mathrm{~Hz}, \mathrm{H}-7$ ), 3.49-3.58 (1H, m, H-12), 3.67 (3H, s, $\left.\mathrm{OC}_{3}{ }_{3}\right), 3.70-3.78$ (1H, m, H-12), 4.57 (1H, bs, H-13), 4.84 (1H, bs, H-13'); ${ }^{13} \mathrm{C}$ NMR (75 MHz, $\mathrm{CDCl}_{3}$ ) $\delta: 15.4$ (C-16), 17.2 (C-15), 19.1 (C-2), 27.3 (C-6), 27.5 (C-11), 37.5 (C-3), 38.3 (C-7),

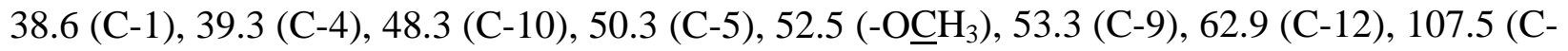
13), 148.4 (C-8), 179.6 (C-14); HRMS m/z 280.20346, calcd. for $\mathrm{C}_{17} \mathrm{H}_{28} \mathrm{O}_{3} 280.20385$.

Epoxy-alcohol 9. To a stirred solution of $8(70 \mathrm{mg}, 0.25 \mathrm{mmol})$ in $\operatorname{dry~} \mathrm{CH}_{2} \mathrm{Cl}_{2}(5 \mathrm{~mL})$ at $0^{\circ} \mathrm{C}$ was added 50\% mCPBA (86 mg, $0.5 \mathrm{mmol}$ ). After stirring for $3 \mathrm{~h}$, the mixture was diluted with $\mathrm{CH}_{2} \mathrm{Cl}_{2}(20 \mathrm{~mL})$ and washed successively with aqueous $\mathrm{Na}_{2} \mathrm{~S}_{2} \mathrm{O}_{5}$ and $\mathrm{NaHCO}_{3}$ solutions. The organic phase was then dried with anhydrous $\mathrm{Na}_{2} \mathrm{SO}_{4}$, the solvent was removed under reduced pressure and the residue was chromatographed on silica gel (petroleum ether:EtOAc, 85:15 to $75: 25)$ to give a product proposed as 9 (67 mg, 90\%) as colorless crystals; mp. $51-53^{\circ} \mathrm{C}$; $[\alpha]_{D}^{20}$ +12.2 (c = 2.5, $\mathrm{CHCl}_{3}$ ); IR (film) v $v_{\max }$ : 3428, 2942, 2869, 1449, 1388, 1248, 1174, 1151, 1134, 1104, 1048, 978, $736 \mathrm{~cm}^{-1}$; ${ }^{1} \mathrm{H}$ NMR (500 MHz, $\left.\mathrm{CDCl}_{3}\right) \delta: 0.82$ (3H, s, H-16), 0.94-1.01 (1H, m, H-11), 1.10-1.14 (1H, m, H-1), 1.16 (3H, s, H-15), 1.29-1.38 (2H, m, H-6, H-7), 1.50-1.60 (5H, m, H-2, H-2', H-3, H-6', H-11'), 1.69-1.77 (4H, m, H-1', H-3', H-9, -OH), 1.90 (1H, dd, J = 2.4, $12.5 \mathrm{~Hz}, \mathrm{H}-5), 1.96$ (1H, ddt, $J=2.1,4.6,12.5 \mathrm{~Hz}, \mathrm{H}-7$ ), 2.57 (1H, d, $J=4.0 \mathrm{~Hz}, \mathrm{H}-13$ ), 2.86 (1H, dd, $J=2.1,4.0$ Hz, H-13'), 3.46 (1H, ddd, $J=5.2,8.6,10.4$ Hz, H-12), 3.63 (1H, dt, $J=5.5$, 
$10.4 \mathrm{~Hz}, \mathrm{H}-12$ '), 3.66 (3H, s, $\left.-\mathrm{OC}_{3}\right) ;{ }^{13} \mathrm{C} \mathrm{NMR}$ (125 MHz, $\left.\mathrm{CDCl}_{3}\right) \delta: 14.9$ (C-16), 16.4 (C-15), 17.6 (C-2), 24.1 (C-6), 25.1 (C-11), 35.8 (C-7), 36.7 (C-3), 37.7 (C-1), 39.4 (C-4), 47.4 (C-10), 49.1 (C-5), 50.7 (-OCH$\left.{ }_{3}\right), 51.9$ (C-13), 52.5 (C-9), 59.2 (C-8), 63.5 (C-12), 178.9 (C-14); MS $(\mathrm{m} / \mathrm{z}) 296\left(\mathrm{M}^{+}\right)$.

Triol 10. To a suspension of $\mathrm{LiAlH}_{4}(37 \mathrm{mg}, 1.0 \mathrm{mmol})$ in dry THF (25 mL) was added a solution of 9 (110 mg, $0.34 \mathrm{mmol})$ in dry THF (25 mL) and the mixture was refluxed for $3 \mathrm{~h}$. After cooling to room temperature, the excess hydride was destroyed by the careful additions of $15 \%$ aqueous $\mathrm{NaOH}$ solution. The solid was removed by filtration through a Celite pad and the organic phase was washed with brine, dried with anhydrous $\mathrm{MgSO}_{4}$, and the solvent was removed under reduced pressure. The residue was purified by silica gel chromatography (silica gel, $\mathrm{CH}_{2} \mathrm{Cl}_{2}: \mathrm{MeOH}$, 95) to give triol 10 (78 mg, 86\%) as colorless crystals; mp. $129-130^{\circ} \mathrm{C}$; IR $(\mathrm{KBr}) v_{\max }: 3330,2928,2861,1477,1450,1076,1051,1031,1000,920 \mathrm{~cm}^{-1}$; ${ }^{1} \mathrm{H}$ NMR (300 $\mathrm{MHz}_{\mathrm{CDCl}}$ ) $\delta: 0.73$ (3H, s, H-16), 0.83 (3H, s, H-15), 0.90-0.99 (1H, m, H-1), 1.19 (3H, s, H13), 1.11-1.34 (5H, m, H-3, H-3', H-5, H-6, H-9), 1.40-1.71 (6H, m, H-1', H-2, H-2', H-6', H-11, H-11'), 1.80-1.97 (2H, m, H-7, H-7'), 2.20 (1H, bs, -OH), $2.66(1 \mathrm{H}, \mathrm{bs},-\mathrm{OH}), 2.82$ (1H, bs, $\mathrm{OH}), 3.07$ (1H, d, $J=11.0 \mathrm{~Hz}, \mathrm{H}-14), 3.44$ (1H, d, $\left.J=11.0 \mathrm{~Hz}, \mathrm{H}-14^{\prime}\right), 3.68$ (2H, bt, $J=5.5 \mathrm{~Hz}$, $\mathrm{H}-12, \mathrm{H} 12$ ); ${ }^{13} \mathrm{C}$ NMR (75 MHz, $\mathrm{CDCl}_{3}$ ) $\delta: 15.7$ (C-16), 17.5 (C-15), 17.8 (C-2), 20.2 (C-6), 24.6 (C-13), 27.9 (C-11), 35.1 (C-3), 37.7 (C-4), 38.9 (C-1), 38.9 (C-10), 43.8 (C-7), 48.8 (C-5), 59.2 (C-9), 62.7 (C-12), 71.6 (C-14), 72.9 (C-8); HRMS m/z 270.21946, calcd. for $\mathrm{C}_{16} \mathrm{H}_{30} \mathrm{O}_{3}$ 270.21950 .

Tosylate 11. To a solution of $\mathbf{1 0}(70 \mathrm{mg}, 0.26 \mathrm{mmol})$ in dry pyridine $(5 \mathrm{~mL})$ was added TsCl (100 mg, $0.52 \mathrm{mmol}$ ) and the mixture was stirred at room temperature for $12 \mathrm{~h}$. The mixture was diluted with EtOAc (10 mL) and washed successively with 5\% aqueous $\mathrm{HCl}$ solution, 5\% aqueous $\mathrm{NaHCO}_{3}$ solution and brine. The organic phase was dried with anhydrous $\mathrm{MgSO}_{4}$, the solvent was removed under reduced pressure and the residue was chromatographed on silica gel (petroleum ether:EtOAc, 9:1) to give 11 (74 mg, 62\%) as white crystals; mp. 160-161 ${ }^{\circ} \mathrm{C}$; IR (KBr) $v_{\max }: 2928,2877,1597,1475,1450,1359,1189,1174,1097,960,856,812 \mathrm{~cm}^{-1}$; ${ }^{1} \mathrm{H}$ NMR (300 MHz, $\mathrm{CDCl}_{3}$ ) $\delta: 0.79$ (3H, s, H-16), 0.83 (3H, s, H-15), 0.99-1.09 (1H, m, H-1), 1.05 (3H, s, H-13), 1.18-1.59 (9H, m, H-1', H-2, H2', H-3, H-3', H-5, H-6, H-6', H-9), 1.64-1.82 (4H, m, H7,H-7', H-11, H-11'), 2.46 (3H, s, Ph- $\underline{\mathrm{H}}_{3}$ ), 3.55 (1H, d, $\left.J=9.2 \mathrm{~Hz}, \mathrm{H}-14\right), 3.70$ (1H, d, $J=9.2$, H-14'), 3.78-3.94 (2H, m, H-12, H-12'), 7.35 (2H, d, $J=8.1$ Hz, Ph- $\underline{\mathrm{H}}), 7.78$ (2H, d, $J=8.4 \mathrm{~Hz}$, Ph- $\left.\underline{H}^{\prime}\right) ;{ }^{13} \mathrm{C}$ NMR (75 MHz, $\mathrm{CDCl}_{3}$ ) $\delta: 15.4$ (C-16), 16.8 (C-15), 17.5 (C-2), 20.3 (C-6), 21.2 (C13), 21.7 ( $\mathrm{Ph}-\underline{\mathrm{CH}}_{3}$ ), 22.7 (C-11), 35.6 (C-3), 36.2 (C-4), 36.8 (C-10), 39.1 (C-1), 39.3 (C-7), 50.2 (C-5), 59.9 (C-9), 64.9 (C-12), 77.8 (C-14), 79.4 (C-8), 127.8 (Ph-ortho), 129.7 (Ph-meta), 132.8 (Ph-para), 144.6 (Ph-ipso); HRMS m/z 406.21758, calcd. for $\mathrm{C}_{23} \mathrm{H}_{34} \mathrm{O}_{4} \mathrm{~S} 406.21778$.

ent-Ambrox 2. To a suspension of $\mathrm{NaI}$ (280 mg, $1.87 \mathrm{mmol}$ ) and activated zinc dust (240 mg, $3.69 \mathrm{mmol})$ in dry DMF (18 mL) was added a solution of 11 (75 mg, $0.18 \mathrm{mmol})$ and the mixture was heated at $110^{\circ} \mathrm{C}$ for $12 \mathrm{~h}$. After cooling the mixture to room temperature, the solution was diluted with $n$-pentane $(20 \mathrm{~mL})$ and filtered. The organic phase was then washed successively with $5 \%$ aqueous $\mathrm{HCl}$ solution, $2 \%$ aqueous $\mathrm{Na}_{2} \mathrm{~S}_{2} \mathrm{O}_{3}$ solution, brine, and dried with anhydrous 
$\mathrm{MgSO}_{4}$. The solvent was removed under reduced pressure. The residue was dissolved in $\mathrm{CH}_{2} \mathrm{Cl}_{2}$ (5 mL) at room temperature and treated with 50\% mCPBA (50 mg). After stirring for $3 \mathrm{~h}$, the mixture was diluted with $\mathrm{CH}_{2} \mathrm{Cl}_{2}(15 \mathrm{~mL})$ and washed with $10 \%$ aqueous $\mathrm{Na}_{2} \mathrm{~S}_{2} \mathrm{O}_{5}$ solution, brine and the organic phase was dried with anhydrous $\mathrm{Na}_{2} \mathrm{SO}_{4}$. After removing the solvent under reduced pressure, the residue was chromatographed on silica gel (petroleum ether:EtOAc, 95:5) to give ent-ambrox (2) (95 mg, 58\%, two steps) as colorless crystals; mp. $75-76^{\circ} \mathrm{C}$, \{lit. ${ }^{21} \mathrm{mp}$. $69-70^{\circ}$; lit. $^{24}$ for enantiomer mp. 77-77.5 $\}$; $[\alpha]_{D}^{20}+27.0\left(\mathrm{c}=1.0, \mathrm{CHCl}_{3}\right),\left\{\right.$ lit. $\left.^{24}[\alpha]_{D}^{20}+21.7\right\}$; IR $(\mathrm{KBr}) v_{\max }$ : 2921, 2869, 2841, 1765, 1456, 1378, 1274, 1218, 1160, 1084, 1068, 1025, 1007 , 979, 955, $943 \mathrm{~cm}^{-1}$; ${ }^{1} \mathrm{H}$ NMR (300 MHz, $\mathrm{CDCl}_{3}$ ) $\delta: 0.84$ (3H, s, H-16), 0.85 (3H, s, H-15), 0.88 (3H, s, H-14), 0.94-1.05 (3H, m, H-1, H-2, H-5), 1.10 (3H, s, H-13), 1.36-1.51 (7H, m, H-2, H1', H-6, H-7, H-7', H-9, H-11), 1.59-1.79 (3H, m, H-3, H-6', H-11'), 1.92-1.98 (1H, m, H-7), 3.79-3.96 (2H, m, H-12, H-12'); ${ }^{13} \mathrm{C}$ NMR (75 MHz, $\mathrm{CDCl}_{3}$ ) $\delta: 15.1$ (C-16), 18.5 (C-2), 20.7 (C6), 21.2 (C-15), 21.2 (C-13), 22.7 (C-11), 33.1 (C-4), 33.6 (C-14), 36.2 (C-10), 39.8 (C-7), 40.0 (C-1), 42.5 (C-3), 57.3 (C-5), 60.1 (C-9), 65.0 (C-12), 79.9 (C-8); MS (m/z) 236 (M ). Anal. Calcd. for $\mathrm{C}_{16} \mathrm{H}_{28} \mathrm{O}_{2}$ : C, 81.29; H, 11.94. Found: C, 81.24; H, 11.65 .

\section{Acknowledgements}

We thank Dr. C.H. Collins for reviewing this article. We also thank the Fundação de Amparo à Pesquisa do Estado de São Paulo (FAPESP) for financial support of this work and a fellowship to RAG.

\section{References and Notes}

1. Ohloff, G. The Fragrance of Ambergris. In Fragrance Chemistry, Theimer, E.T., Ed.; Academic Press: New York, 1982, pp 535.

2. Stoll, M.; Hinder, M. Helv. Chim. Acta 1950, 33, 1251 ibid. 1308.

3. Sell, C. Chem. Ind. 1990, 20, 516.

4. For recent publications see: (a) Castro, J.M.; Salido, S.; Altarejos, J.; Nogueras, M.; Sánchez, A. Tetrahedron 2002, 58, 5941; (b) Ishihara, K.; Ishibashi, H.; Yamamoto, H. J. Am. Chem. Soc. 2002, 124, 3647; (c) Bolster, M.G.; Lagnel, B.M.F.; Jansen, B.J.M.; Morin, C.; Groot, A. Tetrahedron 2001, 57, 8369; (d) Moulines, J.; Lamidey, A.M.; Desvergnes-Breuil, V. Synth. Commun. 2001, 749.

5. Zoretic, P.A.; Fang, H.; Ribeiro, A. A. J. Org. Chem. 1998, 63, 4779 and references cited therein.

6. Haksma, A. A. V. H.; Swarts, H. J.; Jansen, B. J. M.; Groot, A. Tetrahedron 1994, 50, 10073.

7. Kutney, J. P.; Chen, Y. H. Can. J. Chem. 1994, 72, 1570.

8. Kutney, J. P.; Cirera, C. Can. J. Chem. 1997, 75, 1136. 
9. Gonzalez Sierra, M.; Rúveda, E.A.; López, J.T.; Cortés, M.J. Heterocycles 1987, 26, 2801.

10. Bolster, M.G.; Jansen, B.J.M.; Groot, A. Tetrahedron 2001, 57, 5657.

11. Bolster, M.G.; Jansen, B.J.M.; Groot, A. Tetrahedron 2001, 57, 5663.

12. Barrero, A.F.; Alvarez-Manzaneda, E.J.; Altarejos, J.; Salido, S.; Ramos, J.M. Tetrahedron 1993, 49, 10405.

13. Nishi, Y.; Ishihara, H. Jpn. Oil Chem. Soc. 1989, 38, 276.

14. Koyama, H.; Kaku, Y.; Ohno, M. Tetrahedron Lett. 1987, 28, 2863.

15. Barrero, A.F.; Altarejos, J.; Alvarez-Manzaneda, E.J.; Ramos, J.M.; Salido, S. Tetrahedron 1993, 49, 9525.

16. Cambie, R.C.; Joblin, K.N.; Preston, A.F. Aust. J. Chem. 1971, 24, 583.

17. Barton, D.H.R.; Parekh, S.I.; Taylor, D.K.; Tse, C. Tetrahedron Lett. 1994, 35, 5801 and references cited therein.

18. Snowden, R. L.; Eichenberger, J-C.; Linder, S. M.; Sonnay, P.; Vial, C.; Schulte-Elte, K. H. J. Org. Chem. 1992, 57, 955.

19. Nakamura, S.; Ishihara, K.; Yamamoto, H. J. Am. Chem. Soc. 2000, 122, 8131 and references cited therein.

20. Akita, H.; Nozawa, M.; Shimizu, H. Tetrahedron: Asymmetry 1998, 9, 1789.

21. Nunes, F.M.N.; Imamura, P.M. J. Braz. Chem. Soc. 1996, 7, 181. The optical purity of methyl copalate used in this work was evaluated to be $46 \%$ ee based on its optical rotation.

22. Nogueira, R.T.; Giacomini, R.A.; Shepherd, G.; Imamura, P.M. J. Braz. Chem. Soc. 2002, 13, 389.

23. (a) Lombardo, L. Org. Synth. 1987, 65, 81. (b) Lombardo, L. Tetrahedron Lett. 1982, 23, 4293.

24. Ohloff, G.; Giersch, W.; Pickenhagen, W.; Furrer, A.; Frei, B. Helv. Chim. Acta 1985, 68, 2022. 